\title{
MODEL PEMBELAJARAN TEAM ASSISTED INDIVIDUALIZATION (TAI) DENGAN MENGGUNAKAN METODE HYPNOTEACHING
}

\author{
TABRANI. ZA ${ }^{1}$, MULIADI KURDI ${ }^{2}$ ZAHRATI $^{3}$ \\ ${ }^{1}$ Fakultas Agama Islam, Universitas Serambi Mekkah Banda Aceh \\ 2,3Fakultas Tarbiyah dan Keguruan, UIN Ar-Raniry Banda Aceh \\ E-mail : tabraniza@scadindependent.org
}

\begin{abstract}
Abstrak
Berdasarkan hasil pengamatan di SMAN 9 BANDA ACEH, khususnya kelas XI diperoleh permasalahan bahwa kebanyakan peserta didik kurang memahami konsep dan teori fisika, peserta didik juga kurang memahami konsep matematika untuk menyelesaikan konsep dan analisis fisika, penggunaan model pembelajaran tidaklah variatif, sehingga peserta didik lebih banyak mendengarkan penjelasan dari guru, tanpa melibatkan peserta didik secara aktif dalam proses pembelajaran. Kondisi tersebut berpengaruh terhadap hasil belajar, respon dan semangat belajar peserta didik. Tujuan penelitian ini adalah untuk mengetahui pengaruh model pembelajaran team assisted individualization (TAI) dengan menggunakan metode hypnoteaching dan untuk mengetahui respon peserta didik terhadap pelaksanaan pembelajaran fisika melalui model pembelajaran team assisted individualization (TAI) dengan menggunakan metode hypnoteaching terhadap hasil belajar peserta didik pada materi gejala pemanasan global kelas XI SMAN 9 Banda Aceh. Penelitian ini merupakan penelitian lapangan dengan menggunakan metode eksperimen dan desain yang digunakan adalah quasi eksperimen dengan teknik pengambilan sampel secara purposive sampling. Data dikumpulkan melalui soal tes pilihan ganda (pretest dan posttest) dan angket respon peserta didik. Hasil belajar peserta didik kelas XI SMAN 9 Banda Aceh lebih tinggi dengan menggunakan model pembelajaran team assisted individualization (TAI) dengan menggunakan metode Hypnoteaching terhadap hasil belajar peserta didik pada materi gejala pemanasan global, diperoleh nilai rata-rata post-test peserta didik yaitu 60,98 di kelas kontrol dan 76,98 di kelas eksperimen. Hal ini menunjukkan bahwa pengaruh model pembelajran team assisted individualization (TAI) dengan menggunakan metode hypnoteaching pada materi gejala pemanasan global dapat meningkatkan hasil belajar peserta didik kelas XI di SMAN 9 Banda Aceh.
\end{abstract}

Keywords: Model TAI, Respon, Gejala Pemanasan Global, Hypnoteaching 


\section{A. Pendahuluan}

Pendidikan adalah sebuah konsep yang sangat abstrak yang tidak dapat memiliki tujuan-tujuan pendidikan dalam dirinya sendiri, yang bisa memiliki tujuan-tujuan pendidikan adalah manusia-manusia konkret yang terlibat dalam proses pendidikan, seperti guru, peserta didik dan lain-lain. Jadi, tujuan-tujuan pendidikan itu muncul dari situasi konkret tiap individu yang terlibat dalam proses pendidikan. ${ }^{1}$ Berdasarkan pengertian tersebut, pendidikan merupakan suatu usaha yang dilakukan secara sadar dan terencana dalam proses mengembangkan kemampuan atau potensi dirinya untuk memiliki kekuatan spiritual, kepribadian, pengendalian diri, kecerdasan dan keterampilan yang dimiliki oleh peserta didik.

Masalah yang dihadapi dunia pendidikan kita adalah masalah lemahnya proses pembelajaran. Dalam proses pembelajaran, anak kurang didorong untuk mengembangkan kemampuan berfikir. Proses pembelajaran di dalam kelas diarahkan kepada kemampuan anak untuk menghafal informasi, otak anak dipaksa untuk mengingat dan menimbun berbagai informasi tanpa dituntut untuk memahami informasi yang diingatnya itu untuk menghubungkannya dengan kehidupan sehari-hari. ${ }^{2}$ Banyak guru yang kurang memperhatikan emosi dan psikologis peserta didik, sehingga guru dimata peserta didik menjadi sosok yang tidak menyenangkan. Hal ini menyebabkan ketakutan peserta didik terhadap

${ }^{1}$ Doni Koesoema A, Pendidikan Karakter, (Jakarta: Grasindo), 2007, h.78.

2 Wina Sanjaya, Strategi Pembelajaran Berorientasi Standar Proses Pendidikan, (Jakarta: Kencana Prenada Media Group, 2006), h.1. 
kegiatan belajar sehingga membuat peserta didik tidak menyukai mata pelajaran tertentu.

Salah satu cara untuk membuat peserta didik mencapai target (KKM) dan menyukai proses pembelajaran terutama pembelajaran fisika adalah dengan menggunakan model pembelajaran yang dapat diterapkan yaitu model kooperatif (Cooperative Learning). Salah satu model pembelajaran kooperatif yaitu Team Assisted Individualization (TAI), di mana model pembelajaran TAI merupakan tipe pembelajaran kooperatif yang melatih peserta didik berfikir kritis, kreatif, dan efektif. TAI merancang sebuah pembelajaran kelompok dengan cara menyuruh peserta didik bekerja dalam kelompok-kelompok dan bertanggung jawab dalam pengaturan dan pengecekan secara rutin, saling bantu membantu dalam memecahkan masalah dan saling mendorong untuk berprestasi.

Selain itu, penggunaan metode yang baik juga dapat mempengaruhi hasil belajar peserta didik, hypnoteaching sebagai salah satu alternatif metode yang dapat digunakan untuk menciptakan pembelajaran efektif. Hypnoteaching adalah metode pembelajaran yang menggunakan teknik komunikasi yang sangat persuasif dan sugestif untuk menyampaikan mata pelajaran. Tujuannya agar peserta didik mudah dalam memahami materi pelajaran. ${ }^{3}$ Kelebihan dari pembelajaran hypnoteaching yaitu proses belajar mengajar yang lebih dinamis dan ada interaksi yang baik antara pendidik dan peserta didik. Peserta didik dapat berkembang sesuai dengan bakat dan minatnya, proses pemberian

${ }^{3}$ Obee Delapan Setengah, Hypnosis Go: Hidup Lebih Baik, (Jakarta: Bintang Wahyu, 2016), h.106. 
keterampilan banyak diberikan, proses pembelajarannya lebih beragam membuat peserta didik dapat dengan mudah menguasai materi, karena termotivasi lebih untuk belajar.

\section{B. Metode Penelitian}

\section{Rancangan Penelitian}

Rancangan penelitian meliputi metode penelitian dan teknik pengumpulan data. Metode merupakan cara yang digunakan untuk membahas dan meneliti masalah yang terjadi. Adapun metode dalam penelitian ini menggunakan metode eksperimen semu (Quasi Eksperimental) dengan desain Nonequivalent control group design. Penelitian ini dilakukan di sekolah dengan sampel dua kelas (kelas eksperimen dan kelas kontrol) yang diambil secara tidak random. Kedua kelas tersebut sama-sama diberikan tes awal dan tes akhir.

Metode quasi eksperimen ini digunakan untuk mengetahui pengaruh model pembelajaran Team Assisted Individualization (TAI) dengan menggunakan metode Hypnoteaching untuk meningkatkan hasil belajar peserta didik pada materi Gejala Pemansan Global. Dalam rancangan penelitian ini ada dua kelompok objek yaitu kelas eksperimen dan kelas kontrol. Kelas eksperimen diajarkan dengan menggunakan model pembelajaran Team Assisted Individualization (TAI) dengan menggunakan metode Hypnoteaching untuk meningkatkan hasil belajar, sedangkan untuk kelas kontrol diajarkan tanpa menggunakan model pembelajaran Team Assisted Individualization (TAI) dengan menggunakan metode Hypnoteaching. Dengan bentuk rancangan penelitian sebagai berikut: 
Tabel 3.1 Rancangan Penelitian

\begin{tabular}{lllll}
\hline No & Group & Tes Awal & Perlakuan & Tes Akhir \\
\hline 1. & Eksperimen & $\mathrm{Y}_{1}$ & $\mathrm{X}_{1}$ & $\mathrm{Z}_{1}$ \\
\hline 2. & Kontrol & $\mathrm{Y}_{2}$ & - & $\mathrm{Z}_{2}$ \\
\hline
\end{tabular}

Keterangan :

$\mathrm{Y}_{1}=$ Pemberian Tes Awal (pree-test) kelas eksperimen

$\mathrm{Y}_{2}=$ Pemberian Tes Awal (pree-test) kelas kontrol

$\mathrm{X}_{1}=$ Perlakuan kelas eksperimen (model pembelajaran TAI dengan menggunakan metode Hypnoteaching)

$\mathrm{X}_{2} \quad=$ Tidak ada perlakuan

$Z_{1}=$ Pemberian evaluasi akhir (post-test) kelas eksperimen

$Z_{2} \quad=$ Pemberian evaluasi akhir (post-test) kelas kontrol

\section{Populasi dan Sampel Penelitian}

\section{Populasi Penelitian}

Populasi merupakan seluruh objek yang akan diteliti dalam suatu penelitian. ${ }^{4}$ Populasi terjangkau adalah seluruh siswa kelas XI semester II SMAN 9 Banda Aceh, tahun ajaran 2016/2017.

\section{Sampel Penelitian}

${ }^{4}$ Suharsimi, Arikunto, Prosedur Penelitian Suatu Pendekatan Praktik, (Jakarta: Rinika Cipta, 2006), h.130. 
Sampel adalah sebagian atau wakil dari jumlah populasi yang diteliti. ${ }^{5}$ Dalam penelitian ini yang menjadi sampel adalah peserta didik kelas XI IPA 2 dan XI IPA 4 yang terdiri dari 25 peserta didik. Kelas Kontrol (XI IPA4) yang diajarkan dengan metode kontrol dan Kelas Eksperimen $\left(\mathrm{XI} \quad \mathrm{IPA}_{2}\right)$ yang diajarkan dengan Model Pembelajaran Team Assisted Individualiztion (TAI) dengan menggunakan metode Hypnoteaching.

Adapun teknik pengambilan sampel dalam penelitian ini adalah secara purposive sampling. Purposive sampling adalah pengambilan sampel sumber data dengan pertimbangan tertentu. ${ }^{6}$ Jadi pada penelitian ini pengambilan besar sampel ditentukan dengan total sampling. Total sampling adalah teknik penentuan sampel bila semua anggota populasi digunakan sebagai sampel.

\section{Teknik Pengumpulan Data}

Instrumen penelitian adalah alat atau fasilitas yang digunakan oleh peneliti dalam mengumpulkan data agar pekerjaannya lebih mudah dan hasilnya lebih baik, dalam arti lebih cermat, lengkap, dan sistematis sehingga lebih mudah diolah.7 Instrumen yang digunakan di dalam penelitian ini adalah:

5 Suharsimi, Arikunto, Prosedur Penelitian....., h.131.

'Sugiyono, Metode Penelitian Kuantitatif, Kualitatif, dan RED, (Bandung: Alfabeta, CV, 2014), h. 80-81

${ }^{7}$ Arikunto, S., Prosedur Penelitian Suatu Pendekatan Praktek, ( Jakarta: Rineka Cipta, 2006), h. 136 
1. Soal tes, merupakan pertanyaan atau latihan yang digunakan untuk mengukur keterampilan pengetahuan, intelegensi, kemampuan atau bakat yang dimiliki individu maupun kelompok. ${ }^{8}$ Prosedur tes yang digunakan dalam penelitian terbagi menjadi dua, yakni tes awal (pre-test) dan tes akhir (post-test). Tes awal digunakan sebelum pembelajaran dilakukan. Tujuannya adalah untuk mengetahui kemampuan awal siswa sebelum mendapatkan perlakuan, baik di kelas kontrol maupun kelas eksperimen yang mendapat perlakuan berbeda. Kelas kontrol mendapat perlakuan berupa model pembelajaran konvensional, sedangkan kelas eksperimen mendapatkan perlakuan dengan model pembelajaran TAI dengan menggunakan metode Hypnoteaching. Prosedur tes kedua yakni tes akhir (post-test), tes akhir dilakukan untuk mengetahui hasil belajar siswa setelah mendapatkan perlakuan. Adapun bentuk soal tesnya adalah soal pilihan ganda dengan jumlah 20 butir soal.

2. Daftar angket adalah suatu instrumen pengumpulan data dengan mengajukan sejumlah pertanyaan yang telah dipersiapkan secara tertulis dan diedarkan kepada peserta didik yang menjadi sampel penelitian. Angket yang disusun sesuai dengan masalah yang sedang diteliti, dalam hal ini angket yang digunakan adalah angket tertutup. Dimana untuk setiap pertanyaan telah tersedia jawabannya. Responden hanya dapat memilih salah satu jawaban tersebut yang dianggap sesuai dengan pengalaman peserta didik.

${ }^{8}$ Ridhwan, 2012, Belajar Mudah Penelitian untuk Guru-Karyawan dan Peneliti Pemula, (Bandung: Alfabeta), h. 76 


\section{E. Teknik Analisis Data}

\section{Analisis Tes Hasil Belajar}

Tahap penganalisaan data merupakan tahap yang paling penting dalam suatu penelitian, karena pada tahap inilah peneliti dapat merumuskan hasil-hasil penelitiannya. ${ }^{9}$ Setelah data diperoleh, selanjutnya data ditabulasikan ke dalam data frekuensi, kemudian diolah dengan meggunakan langkah-langkah sebagai berikut:

a. Tentukan rentang $(\mathrm{R})$ ialah data terbesar dikurangi data terkecil.

b. Tentukan banyaknya kelas interval (K) dengan menggunakan aturan

Sturges, yaitu: banyak kelas $=1+(3,3) \log n$

c. Tentukan panjang kelas interval $\mathrm{P}$ dengan rumus:

$$
\mathrm{P}=\frac{\text { rentang }}{\text { banyak kelas }}
$$

d. Pilih ujung bawah kelas interval pertama. Untuk ini bisa diambil sama dengan data terkecil atau nilai data yang lebih kecil dari data terkecil tetapi selisihnya harus kurang dari panjang kelas yang telah di tentukan.

1. Mencari nilai rata-rata

Untuk menghitung rata-rata menggunakan rumus:

${ }^{9}$ Sudjana, Metode Statistik, (Bandung: Tarsito, 2002), h. 273. 


$$
\bar{x}=\frac{\sum f i x i}{\sum f i}
$$

Keterangan:

$$
\begin{aligned}
& \bar{x}=\text { skor rata- rata siswa } \\
& f i=\text { frekuensi kelas interval data } \\
& x i=\text { nilai tengah }
\end{aligned}
$$

2. Menghitung varians $\left(\mathrm{s}^{2}\right)$

Menentukan varians, rumus yang di gunakan yaitu:

$$
s^{2}=\frac{\sum f_{i}\left(\left[x_{i}-\bar{x}\right)\right]^{2}}{\mathbf{n}-\mathbf{1}}
$$

Keterangan:

$$
\begin{array}{ll}
S^{2} & =\text { varians } \\
\mathrm{n} & =\text { banyak peserta didik }
\end{array}
$$

3. Uji homogenitas varians

Homogenitas varians berguna untuk mengatasi apakah penilaian ini berasal dari populasi yang sama atau bukan. Untuk menguji kesamaan varians, rumus yang di gunakan yaitu:

$$
\mathrm{F}=\frac{\text { varians terbesar }}{\text { varians terkecil }}
$$


4. Uji Normalisasi Sebaran Data

Menguji normalitas data terlebih dahulu di buat kedalam daftar distribusi kemudian di hitung rata-rata varians dan simpangan baku. Untuk menguji kenormalan sampel, rumus yang di gunakan yaitu:

$$
X^{2}=\sum_{i=l}^{k} \frac{\left([O i-E i) \rrbracket^{2}\right.}{E i}
$$

keterangan:

$$
\begin{aligned}
& \mathrm{E}_{\mathrm{i}}=\text { Frekuensi diharapkan } \\
& \mathrm{O}_{\mathrm{i}}=\text { Frekuensi pengamatan }
\end{aligned}
$$

5. Hasil penelitian yang berupa tes awal dan tes akhir dianalisis dengan menggunakan uji $\mathrm{t}$

$$
t=\frac{\bar{x}_{1}-\bar{x}_{2}}{S \sqrt{\frac{1}{n_{1}}+\frac{1}{n_{2}}}}
$$

Dengan

$$
S^{2}=\frac{\left(n_{1}-1\right) S_{1}^{2}+\left(n_{2}-1\right) S_{2}^{2}}{\left(n_{1}+n_{2}\right)-2}
$$

Keterangan :

$$
n_{1}=\text { Jumlah peserta didik pada kelas eksperimen }
$$


$n_{2}=$ Jumlah peserta didik pada kelas kontrol

$\bar{x}_{1}=$ Nilai rata-rata pada kelas eksperimen

$\bar{x}_{2}=$ Nilai rata-rata pada kelas kontrol

$\mathrm{S}=$ Varians (simpangan baku)

$S_{1}^{2}=$ Varians dari kelas eksperimen

$S_{2}^{2}=$ Varians dari kelas kontrol. ${ }^{10}$

\section{Analisis Data Respon Peserta Didik}

Data respon siswa diperoleh dari angket yang diedarkan kepada seluruh siswa setelah proses pembelajaran selesai. Data yang diperoleh melalui angket dianalisis dengan menggunakan persentase. Menurut Suharsimi Arikunto rumus yang digunakan untuk menghitung persentase dari setiap respon siswa adalah:

$$
P=\frac{f}{N} \times 100 \%
$$

Keterangan:

$P \quad$ : Angka persentase

$f \quad$ : Frekuensi jumlah respon siswa tiap aspek yang muncul

$N \quad$ : Jumlah seluruh siswa

100\% : Nilai konstan.

${ }^{10}$ Sudjana. Metoda Statistika. (Bandung : Tarsito, 2005). h. 239 
Respons peserta didik dikatakan efektif jika jawaban peserta didik terhadap pernyataan positif untuk setiap aspek yang direspon. ${ }^{11}$

\section{F. Uji Hipotesis}

Sebelum pengujian hipotesis penelitian perlu terlebih dahulu dirumuskan hipotesis statistik sebagai berikut:

$H_{o}:$ Pengaruh model pembelajaran Team Assisted Individualization (TAI) dengan menggunakan metode Hypnoteaching tidak dapat meningkatkan hasil belajar peserta didik pada pembelajaran fisika di SMAN 9 Banda Aceh

Ha:Pengaruh model pembelajaran Team Assisted Individualization (TAI) dengan menggunakan metode Hypnoteaching dapat meningkatkan hasil belajar peserta didik pada pembelajaran fisika di SMAN 9 Banda Aceh

Pengujian dilaksanakan pada taraf signitifikan $\alpha=0,05$ (5\%) dengan derajat kebebasan $d k=\left(n_{1}+n_{2}-2\right)$ dengan kriteria pengujian, terima $H_{0}$ jika thitung $\leq \mathrm{t}_{(1-\mathrm{a})}$ dengan $\mathrm{t}_{(1-\mathrm{\alpha})}$ di dapat dari daftar distribusi t-student. Untuk $\mathrm{t}_{\text {hitung }} \geq$ $\mathbf{t}_{(1-\alpha)}$, hipotesis $\mathrm{H}_{\alpha}$ diterima.

Adapun ketentuan untuk penerimaan dan penolakan hipotesis adalah:

1. Menolak hipotesis nihil $\left(H_{0}\right)$ dan menerima hipotesis alternatif $\left(H_{a}\right)$ bila,

${ }^{11}$ Suharsimi Arikunto. Prosedur Penelitian Suatu Pendekatan Praktek. (Jakarta: RinekaCipta, 2006). h. 32 


$$
t_{\text {hitung }} \geq t_{\text {tabel }}
$$

2. Menerima hipotesis nihil $\left(H_{0}\right)$ dan menolak hipotesis alternatif $\left(H_{a}\right)$ bila,

$$
t_{\text {hitung }}<t_{\text {tabel }}
$$

\section{G. Hasil Penelitian Dan Pembahasan}

\section{Hasil Penelitian}

\section{Penyajian Data}

\section{a. Data Hasil Belajar}

\section{1) Nilai Pre-test dan Post-test Kelas Kontrol}

Berdasarkan hasil penelitian diperoleh data hasil belajar peserta didik untuk kelas kontrol sebagai berikut:

Tabel 4.1 Data Nilai Pre-test dan Post-test Peserta Didik Kelas XI IPA 4 (Kelas Kontrol)

\begin{tabular}{llll}
\hline \multirow{2}{*}{ No } & \multirow{2}{*}{ Nama } & Nilai & Post-test \\
\cline { 3 - 4 } & & Pre-test & $\mathbf{( 4 )}$ \\
\hline $\mathbf{( 1 )}$ & $\mathbf{( 2 )}$ & $\mathbf{( 3 )}$ & 80 \\
\hline 1 & $\mathrm{~A}_{1}$ & 60 & 55 \\
\hline 2 & $\mathrm{~A}_{2}$ & 35 & 40 \\
\hline 3 & $\mathrm{~A}_{3}$ & 25 & 70 \\
\hline 4 & $\mathrm{~A}_{4}$ & 50 & \\
\hline
\end{tabular}




\begin{tabular}{|c|c|c|c|}
\hline 5 & $\mathrm{~A}_{5}$ & 35 & 55 \\
\hline 6 & $\mathrm{~A}_{6}$ & 30 & 50 \\
\hline 7 & $\mathrm{~A}_{7}$ & 65 & 75 \\
\hline 8 & $\mathrm{~A}_{8}$ & 65 & 80 \\
\hline 9 & $\mathrm{~A}_{9}$ & 35 & 55 \\
\hline 10 & $\mathrm{~A}_{10}$ & 55 & 65 \\
\hline 11 & $\mathrm{~A}_{11}$ & 60 & 80 \\
\hline 12 & $\mathrm{~A}_{12}$ & 45 & 50 \\
\hline 13 & $\mathrm{~A}_{13}$ & 45 & 65 \\
\hline 14 & $\mathrm{~A}_{14}$ & 35 & 55 \\
\hline 15 & $\mathrm{~A}_{15}$ & 50 & 75 \\
\hline 16 & $\mathrm{~A}_{16}$ & 35 & 60 \\
\hline 17 & $\mathrm{~A}_{17}$ & 55 & 70 \\
\hline 18 & $\mathrm{~A}_{18}$ & 50 & 45 \\
\hline 19 & $\mathrm{~A}_{19}$ & 55 & 75 \\
\hline 20 & $\mathrm{~A}_{20}$ & 50 & 45 \\
\hline 21 & $\mathrm{~A}_{21}$ & 65 & 85 \\
\hline 22 & $\mathrm{~A}_{22}$ & 35 & 45 \\
\hline 23 & $\mathrm{~A}_{23}$ & 25 & 40 \\
\hline 24 & $\mathrm{~A}_{34}$ & 40 & 70 \\
\hline 25 & $\mathrm{~A}_{25}$ & 25 & 50 \\
\hline
\end{tabular}

Sumber: Data Hasil Penelitian Peserta Didik Kelas Kontrol (Tahun 2017)

\section{2) Data Nilai Pre-test dan Post-test Kelas Eksperimen}

Berdasarkan hasil penelitian diperoleh hasil belajar siswa untuk kelas eksperimen sebagai berikut: 
Tabel 4.2 Data Nilai Pre-test dan Post-test Peserta Didik Kelas XI IPA 2 (Kelas Eksperimen)

\begin{tabular}{|c|c|c|c|}
\hline \multirow{2}{*}{ No } & \multirow{2}{*}{ Nama } & \multicolumn{2}{|l|}{ Nilai } \\
\hline & & Pre-test & Post-test \\
\hline (1) & (2) & (3) & (4) \\
\hline 1 & $\mathrm{~A}_{1}$ & 35 & 65 \\
\hline 2 & $\mathrm{~A}_{2}$ & 50 & 85 \\
\hline 3 & $\mathrm{~A}_{3}$ & 55 & 80 \\
\hline 4 & $\mathrm{~A}_{4}$ & 25 & 65 \\
\hline 5 & $\mathrm{~A}_{5}$ & 60 & 95 \\
\hline 6 & $\mathrm{~A}_{6}$ & 55 & 80 \\
\hline 7 & $\mathrm{~A}_{7}$ & 25 & 50 \\
\hline 8 & $\mathrm{~A}_{8}$ & 45 & 80 \\
\hline 9 & $\mathrm{~A}_{9}$ & 50 & 90 \\
\hline 10 & $\mathrm{~A}_{10}$ & 30 & 65 \\
\hline 11 & $\mathrm{~A}_{11}$ & 50 & 75 \\
\hline 12 & $\mathrm{~A}_{12}$ & 55 & 90 \\
\hline 13 & $\mathrm{~A}_{13}$ & 40 & 70 \\
\hline 14 & $\mathrm{~A}_{14}$ & 55 & 85 \\
\hline 15 & $\mathrm{~A}_{15}$ & 35 & 70 \\
\hline 16 & $\mathrm{~A}_{16}$ & 50 & 75 \\
\hline 17 & $\mathrm{~A}_{17}$ & 65 & 90 \\
\hline 18 & $\mathrm{~A}_{18}$ & 30 & 55 \\
\hline 19 & $\mathrm{~A}_{19}$ & 40 & 65 \\
\hline 20 & $\mathrm{~A}_{20}$ & 60 & 90 \\
\hline
\end{tabular}




\begin{tabular}{llll}
\hline 21 & $\mathrm{~A}_{21}$ & 65 & 95 \\
\hline 22 & $\mathrm{~A}_{22}$ & 60 & 80 \\
\hline 23 & $\mathrm{~A}_{23}$ & 65 & 95 \\
\hline 24 & $\mathrm{~A}_{24}$ & 30 & 50 \\
\hline 25 & $\mathrm{~A}_{25}$ & 50 & 85 \\
\hline
\end{tabular}

Sumber: Data Hasil Penelitian Peserta Didik Kelas Eksperimen (Tahun 2017)

\section{Data Respon Peserta Didik}

Berdasarkan hasil penelitian diperoleh data respon peserta didik untuk kelas Eksperimen sebagai berikut

Tabel 4.3 Hasil Angket Respon Peserta Didik

\begin{tabular}{|c|c|c|c|c|c|}
\hline \multirow{2}{*}{ No } & \multirow{2}{*}{ Pernyataan } & \multicolumn{4}{|c|}{ Frekuensi (f) } \\
\hline & & SS & $S$ & TS & STS \\
\hline (1) & (2) & (3) & (4) & (5) & (6) \\
\hline 1 & $\begin{array}{l}\text { Saya merasa puas adanya pembelajaran } \\
\text { model pembelajaran TAI dengan } \\
\text { menggunakan metode Hypnoteaching. }\end{array}$ & 18 & 7 & 0 & 0 \\
\hline 2 & $\begin{array}{l}\text { Model pembelajaran TAI dengan } \\
\text { menggunakan metode Hypnoteaching } \\
\text { dapat menghilangkan rasa bosan saat } \\
\text { proses kegiatan belajar mengajar. }\end{array}$ & 5 & 19 & 1 & 0 \\
\hline 3 & $\begin{array}{l}\text { Dalam model pembelajaran TAI dengan } \\
\text { menggunakan metode Hypnoteaching } \\
\text { memotivasi saya untuk belajar semakin } \\
\text { meningkat. }\end{array}$ & 7 & 17 & 1 & 0 \\
\hline
\end{tabular}




\begin{tabular}{|c|c|c|c|c|c|}
\hline 4 & $\begin{array}{l}\text { Model pembelajaran TAI dengan } \\
\text { menggunakan metode Hypnoteaching } \\
\text { membuat saya semangat untuk } \\
\text { mempelajari pokok materi Gejala } \\
\text { Pemanasan Global. }\end{array}$ & 5 & 20 & 0 & 0 \\
\hline 5 & $\begin{array}{l}\text { Model pembelajaran } \text { TAI dengan } \\
\text { menggunakan metode Hypnoteaching } \\
\text { membuat saya lebih aktif dalam } \\
\text { pembelajaran. }\end{array}$ & 16 & 9 & 0 & 0 \\
\hline 6 & $\begin{array}{l}\text { Model pembelajaran TAI dengan } \\
\text { menggunakan metode Hypnoteaching } \\
\text { membuat saya bekerja sama dengan } \\
\text { teman-teman dalam pembelajaran. }\end{array}$ & 0 & 23 & 2 & 0 \\
\hline
\end{tabular}

\begin{tabular}{|c|c|c|c|c|c|}
\hline 7 & $\begin{array}{l}\text { Saya setuju pembelajaran TAI dengan } \\
\text { menggunakan metode Hypnoteaching } \\
\text { sangat cocok diterapkan pada pokok } \\
\text { materi Gejala Pemanasan Global. }\end{array}$ & 21 & 4 & 0 & 0 \\
\hline 8 & $\begin{array}{l}\text { Model pembelajaran TAI dengan } \\
\text { menggunakan metode Hypnoteaching } \\
\text { dapat diterapkan pada materi pelajaran } \\
\text { lain. }\end{array}$ & 2 & 22 & 1 & 0 \\
\hline
\end{tabular}

Saya merasa dari awal pembelajaran, sudah tertarik dengan model

9 pembelajaran TAI dengan menggunakan $\begin{array}{lllll}3 & 19 & 3 & 0\end{array}$ metode Hypnoteaching. 
Saya setuju bahwa model pembelajaran

10 TAI dengan menggunakan metode Hypnoteaching adalah model yang efektif $\begin{array}{llll}8 & 17 & 0 & 0\end{array}$ dan inovatif.

Dengan model pembelajaran TAI dengan menggunakan metode Hypnoteaching

11 saya lebih mudah memahami pokok $9 \begin{array}{llll}16 & 0 & 0\end{array}$ materi Gejala Pemanasan Global.

\begin{tabular}{llcccc}
\hline $\begin{array}{l}\text { Saya yakin model pembelajaran TAI } \\
\text { dengan menggunakan metode }\end{array}$ & & & & \\
$\begin{array}{l}\text { Hypnoteaching dapat meningkatkan hasil } \\
\text { belajar saya. }\end{array}$ & 4 & 0 & 0 \\
\hline Jumlah & 98 & 194 & 8 & 0 \\
\hline Rata-Rata & 8,1 & 16, & 0,6 & 0 \\
& 6 & 16 & 6 & \\
& & & & \\
&
\end{tabular}

Sumber: Data Respon Respon Peserta Didik (Tahun 2017)

b) Perhitungan Uji Homogenitas Varians

Fungsi uji homogenitas adalah untuk mengetahui apakah sampel ini berhasil dari populasi dengan varians yang sama, sehingga hasil dari penelitian ini berlaku bagi populasi.

1. Homogenitas Varians Pre-test

Berdasarkan hasil nilai Pre-test kelas kontrol dan kelas eksperimen, maka diperoleh $(\overline{\bar{X}})=45,02$ dan $\mathrm{S}^{2}=167,76$ untuk kelas kontrol dan sedangkan untuk kelas eksperimen $(\overline{\mathrm{X}})=47,18$ dan $\mathrm{S}^{2}=169,56$ 
Hipotesis yang akan di uji pada taraf signifikan $\alpha=0,05$, yaitu:

Ho : $\delta_{1}^{2}=\delta_{2}^{2}$

Ha : $\delta_{1}^{2}>\delta_{2}^{2}$

Pengujian ini adalah uji pihak kanan dan pihak kiri maka kriteria pengujian adalah "Tolak Ho jika F>F $\alpha\left(n_{1}-1, n_{2}-1\right)$ dalam hal lain Ho diterima".

Berdasarkan perhitungan di atas maka untuk mencari homogenitas varians dapat digunakan rumus sebagai berikut:

$$
\begin{aligned}
F & =\frac{\text { Varian Terbesar }}{\text { Varian terkecil }} \\
& =\frac{169,56}{167,76} \\
& =1,01
\end{aligned}
$$

Berdasarkan data distribusi F diperoleh:

$$
\begin{aligned}
\mathrm{F}>\mathrm{F} & =\mathrm{F}(0,05)(25-1,25-1) \\
= & \mathrm{F}(0,05)(24,24) \\
& =1,98
\end{aligned}
$$

Ternyata $\mathrm{F}$ hitung $<\mathrm{F}$ tabel atau 1,01 $<1,98$ maka dapat disimpulkan bahwa kedua varian homogen untuk data nilai Pre-test.

2. Homogenitas Varians Pos-test

Berdasarkan hasil nilai Pos-test kelas kontrol dan kelas eksperimen, maka diperoleh $\bar{x}=60,98$ dan $S^{2}=194,76$ untuk kelas kontrol dan sedangkan untuk kelas eksperimen $\overline{\bar{x}}=76,98$ dan $\mathrm{S}^{2}=173,76$ Hipotesis yang akan di uji pada taraf signifikan $\alpha=0,05$, yaitu:

Ho : $\delta_{1}^{2}=\delta_{2}^{2}$ 


$$
\mathrm{Ha}: \delta_{1}^{2}>\delta_{2}^{2}
$$

Pengujian ini adalah uji pihak kanan dan pihak kiri maka kriteria pengujian adalah " Tolak Ho jika F>F $\alpha\left(n_{1}-1, n_{2}-1\right)$ dalam hal lain Ho diterima".

Berdasarkan perhitungan di atas maka untuk mencari homogenitas varians dapat digunakan rumus sebagai berikut:

$$
\begin{aligned}
F & =\frac{\text { Varian Terbesar }}{\text { Varian terkecil }} \\
& =\frac{194,76}{173,76} \\
& =1,12
\end{aligned}
$$

Berdasarkan data distribusi F diperoleh:

$$
\begin{aligned}
\mathrm{F}>\mathrm{F} \alpha\left(n_{1}-1, n_{2}-1\right) & =\mathrm{F}(0,05)(25-1,25-1) \\
& =\mathrm{F}(0,05)(24,24) \\
& =1,98
\end{aligned}
$$

Ternyata $\mathrm{F}_{\text {hitung }}<\mathrm{F}_{\text {tabel }}$ atau 1,12 < 1,98 maka dapat disimpulkan bahwa kedua varian homogen untuk data nilai Posttest.

\section{c) Pengujian Hipotesis}

Statistik yang digunakan untuk meguji hipotesis adalah uji-t, adapun rumusan hipotesis yang akan diuji adalah sebagai berikut:

$$
\begin{aligned}
& H_{o}: \mu_{1}=\mu_{2} \\
& H_{a}: \mu_{1}>\mu_{2}
\end{aligned}
$$

Dimana:

$H_{o}$ : Pengaruh model pembelajaran Team Assisted Individualization (TAI) dengan menggunakan metode Hypnoteaching tidak dapat 
meningkatkan hasil belajar peserta didik pada pembelajaran fisika di SMAN 9 Banda Aceh.

$H a$ : Pengaruh model pembelajaran Team Assisted Individualization (TAI) dengan menggunakan metode Hypnoteaching dapat meningkatkan hasil belajar peserta didik pada pembelajaran fisika di SMAN 9 Banda Aceh.

Berdasarkan hasil pengolahan data di atas, untuk lebih jelasnya dapat dilihat pada tabel berikut:

Tabel 4.16 Hasil Pengolahan Data Penelitian

\begin{tabular}{llll}
\hline No & Hasil Penelitian & Kelas Eksperimen & Kelas Kontrol \\
\hline 1 & Mean data tes akhir $(\bar{x})$ & 76,98 & \\
& & & 60,98 \\
\hline 2 & Varian tes akhir (S2) & 173,76 & 194,76 \\
\hline 3 & Standar deviasi tes akhir (S) & 13,1 & 13.9 \\
\hline 4 & Uji normalitas data $\left(\chi^{2}\right)$ & 23,64 & 10,28 \\
\hline
\end{tabular}

Sumber: Hasil Pengolahan Data (2017)

Pengujian hipotesis pada penelitian ini menggunakan data post-test peserta didik dengan menggunakan perhitungan nilai rata-rata dan nilai standar deviasi pada kelas kontrol dan kelas eksperimen. Berdasarkan perhitungan di atas diperoleh data post-test untuk kelas kontrol $\overline{\bar{x}}=60,98$, $\mathrm{S}=13,9$ dan $\mathrm{S}^{2}=194,76$. Sedangkan untuk kelas eksperimen $\bar{x}=76,98, \mathrm{~S}=$ 13,1 dan $S^{2}=173,76$. Untuk menghitung nilai deviasi gabungan ke dua sampel maka diperoleh: 


$$
\begin{aligned}
& S^{2}=\frac{\left(n_{1}-1\right) S_{1}^{2}+\left(n_{2}-1\right) S_{2}^{2}}{\left(n_{1}+n_{2}\right)-2} \\
& \mathbf{S}^{2}=\frac{(25-1) 194,76+(25-1) 173,76}{(25+25)-2} \\
& \mathbf{S}^{2}=\frac{(24) 194,76+(24) 173,76}{50-2} \\
& \mathbf{S}^{2}=\frac{4674,24+4170,24}{48} \\
& \mathbf{S}^{2}=\frac{8844,48}{48} \\
& \mathbf{S}^{2}=184,26 \\
& \quad S=\sqrt{184,26} \\
& S=13,5
\end{aligned}
$$

Berdasarkan perhitungan di atas, di peroleh $S=13,5$ maka dapat dihitung nilai uji- $t$ sebagai berikut:

$$
\begin{aligned}
t & =\frac{\overline{\mathbf{x}}_{1}-\overline{\mathbf{x}}_{2}}{\mathrm{~s} \sqrt{\frac{1}{\mathrm{n}_{1}}+\frac{1}{\mathbf{n}_{2}}}} \\
= & \frac{76,98 \mid 60,98}{13,5 \sqrt{\frac{1}{25}+\frac{1}{25}}} \\
& =\frac{16}{13,5 \sqrt{0,08}} \\
& =\frac{16}{(13,5)(0,28)} \\
& =\frac{16}{3,78} \\
& =4,23
\end{aligned}
$$


Berdasarkan langkah-langkah yang telah diselesaikan di atas, maka diperoleh hasil $t_{\text {hitung }}=4,23$. Kemudian dicari $t_{\text {tabel }}$ dengan $(\mathrm{dk})=\left(\mathrm{n}_{1}+\mathrm{n}_{2-}\right.$ $2), \mathrm{dk}=(25+25-2)=48$ pada taraf signifikan $\alpha=0,05$ maka dari tabel distribusi t di peroleh nilai $\mathrm{t}_{(0,95)(48)}=1,68$. Karena $\boldsymbol{t}_{\text {hitung }}>\boldsymbol{t}_{\text {tabel }}$ yaitu $4,23>$ 1,68 dengan demikian $H_{a}$ diterima dan $H_{0}$ ditolak sehingga dapat disimpulkan bahwa pengaruh model pembelajaran Team Assisted Individualization (TAI) dengan menggunakan metode Hypnoteaching dapat meningkatkan hasil belajar fisika siswa kelas XI di SMAN 9 Banda Aceh.

Berdasarkan data tersebut dapat dikatakan bahwa pengaruh model pembelajaran Team Assisted Individualization (TAI) dengan menggunakan metode Hypnoteaching berpengaruh terhadap hasil belajar fisika siswa dibandingkan pembelajaran tanpa pengaruh model pembelajaran Team Assisted Individualization (TAI) dengan menggunakan metode Hypnoteaching. Hal ini dapat diinterpretasikan dalam bentuk grafik sebagai berikut:

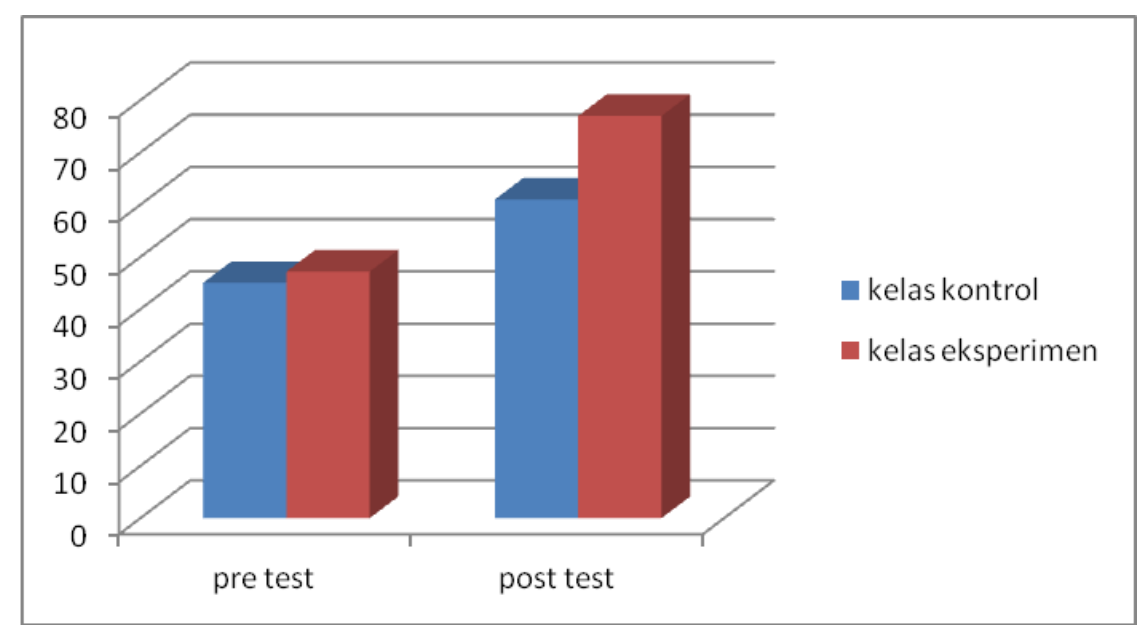


Gambar 4.1 Nilai Rata-Rata Hasil Belajar Kelas Eksperimen dengan Kelas Kontrol

\section{d) Pengolahan Data Angket Respon Peserta Didik Terhadap Pengaruh Model Pembelajaran TAI Dengan Menggunakan Metode Hypnoteaching}

Berdasarkan angket respon peserta didik yang diisi oleh 25 peserta didik kelas XI IPA 2 yang diajarkan menggunakan pengaruh model pembelajaran TAI dengan menggunakan metode Hypnoteaching setelah mengikuti pembelajaran pada materi gejala pemanasan global diperoleh hasil dengan rincian tabel berikut:

Tabel 4.17 Hasil Angket Respon Peserta Didik

\begin{tabular}{|c|c|c|c|c|c|c|c|c|c|}
\hline \multirow{3}{*}{ No } & \multirow{3}{*}{ Pernyataan } & \multicolumn{4}{|c|}{ Frekuensi (f) } & \multicolumn{4}{|c|}{ Persentase (\%) } \\
\hline & & & & $\mathbf{T}$ & ST & $S$ & $\mathbf{S}$ & $\mathrm{T}$ & ST \\
\hline & & & 5 & $S$ & $S$ & $\mathbf{S}$ & & $\mathbf{S}$ & $\mathbf{S}$ \\
\hline \multirow[t]{2}{*}{ (1) } & (2) & (3) & (4 & (5 & (6) & & $(8$ & (9) & (10 \\
\hline & & & ) & ) & & ) & ) & ) & ) \\
\hline
\end{tabular}

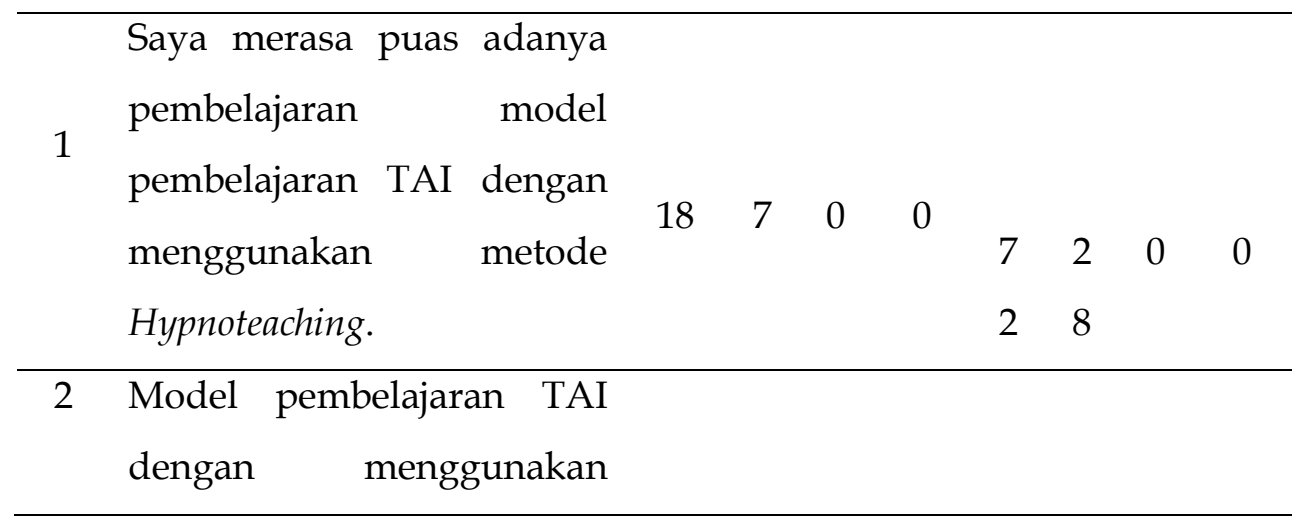




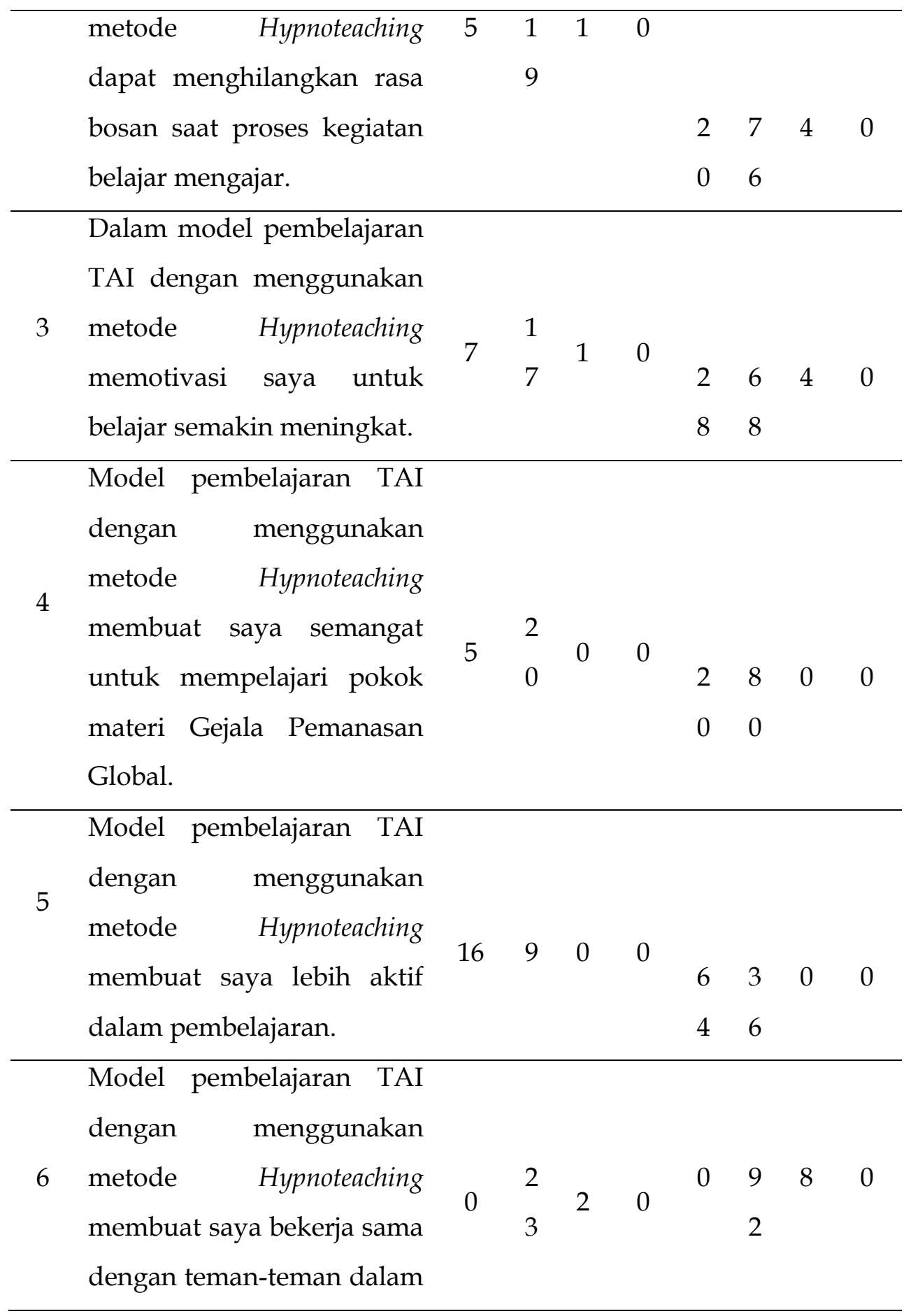


pembelajaran.

Saya setuju pembelajaran

TAI dengan menggunakan

metode Hypnoteaching

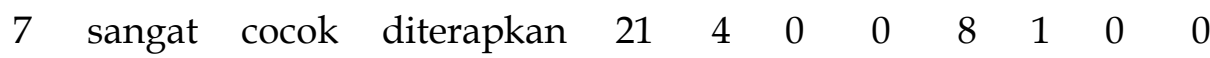
pada pokok materi Gejala

46

Pemanasan Global.

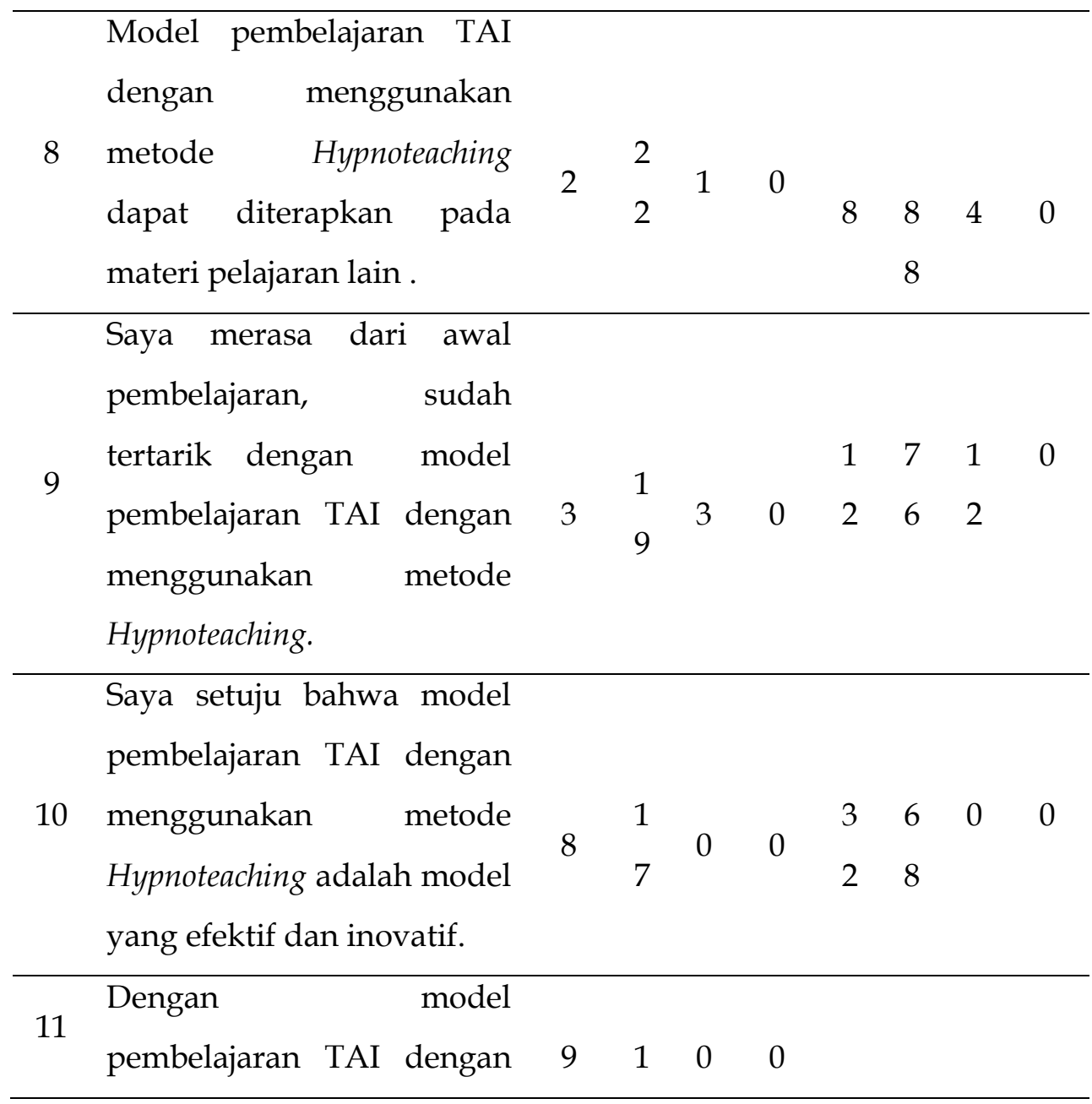




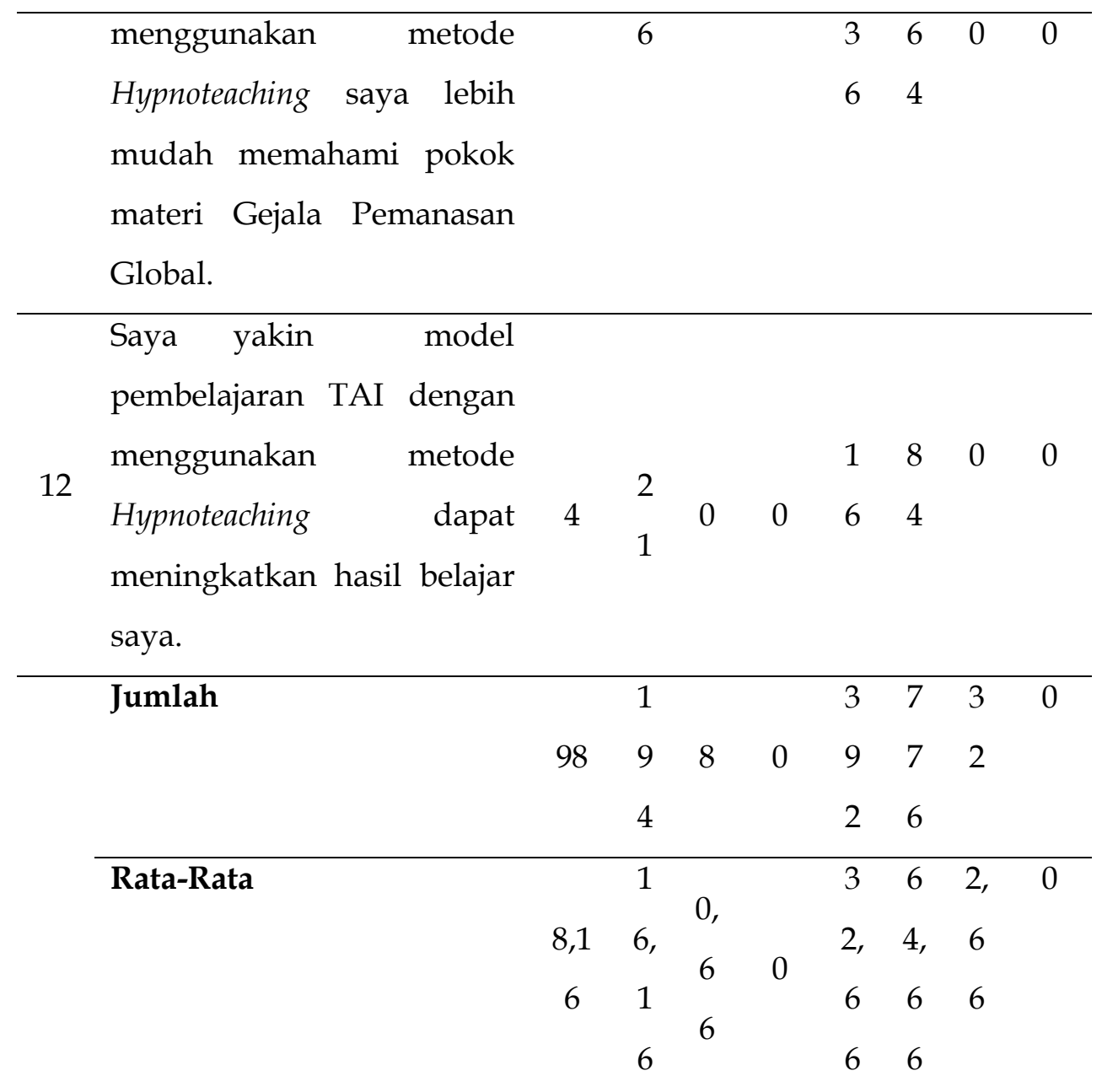

Sumber: Hasil Pengolahan Data (Tahun 2017)

Respon belajar peserta didik yang diisi 25 peserta didik setelah mengikuti pembelajaran dengan pengaruh model pembelajaran Team Assisted Individualization (TAI) dengan menggunakan metode Hypnoteaching terhadap hasil belajar peserta didik pada materi gejala pemanasan global di SMAN 9 Banda Aceh kelas XI IPA2, dapat kita lihat bahwa jawaban respon peserta didik dari 12 pernyataan yaitu peserta didik menjawab 
"sangat setuju" dengan nilai rata-rata 32,66\%, peserta didik menjawab "setuju" dengan nilai rata-rata 64,66\%, peserta didik menjawab "tidak setuju" dengan nilai rata-rata 2,66\%, dan peserta didik menjawab "sangat tidak setuju" dengan nilai rata-rata $0 \%$. Dari hasil tersebut dapat dikatakan bahwa positif terhadap pengaruh model pembelajaran Team Assisted Individualization (TAI) dengan menggunakan metode Hypnoteaching, karena jawaban peserta didik pada setiap pernyataan ratarata memilih jawaban "setuju" dengan persentase $64,66 \%$.

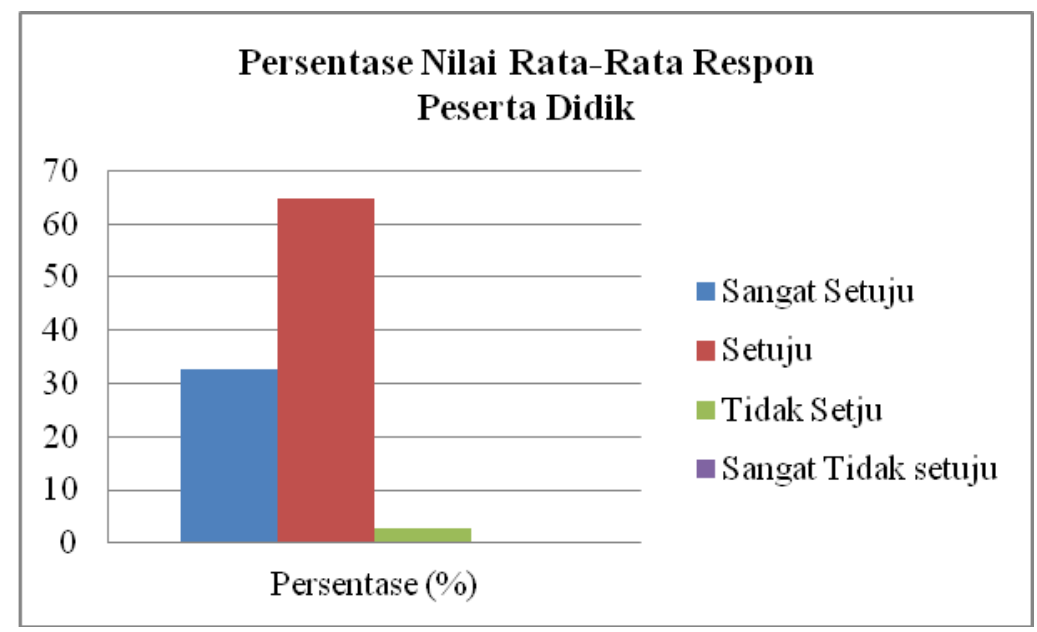

Gambar 4.2 Persentase Nilai Rata-Rata Respon Peserta Didik

\section{H. Pembahasan Hasil Penelitian}

\section{Hasil Belajar Peserta Didik.}

Berdasarkan hasil analisis data nilai post-test pada peserta didik yang dibelajarkan dengan model pembelajaran Team Assisted Individualization (TAI) dengan menggunakan metode Hypnoteaching dengan peserta didik yang dibelajarkan dengan metode konvensional 
dapat dilihat bahwa peserta didik yang dibelajarkan model pembelajaran Team Assisted Individualization (TAI) dengan menggunakan metode Hypnoteaching mencapai nilai post-test rata-rata 76,98, sedangkan pada peserta didik yang dibelajarkan dengan model konvensional mendapatkan nilai 60,98. Hal ini menunjukkan bahwa hasil belajar peserta didik dengan menggunakan model pembelajaran Team Assisted Individualization (TAI) dengan menggunakan metode Hypnoteaching lebih tinggi dibandingkan hasil belajar dengan menggunakan model konvensional dan rata-rata peserta didik mencapai nilai KKM. Adapun nilai KKM mata pelajaran fisika di SMAN 9 Banda Aceh adalah 70.

Peningkatan hasil peserta didik terjadi karena penggunaan model pembelajaran Team Assisted Individualization (TAI) merupakan salah satu bentuk dari pembelajaran kooperatif yang pembelajarannya menggunakan kombinasi pembelajaran kelompok dengan pembelajaran individual12, di mana model pembelajaran TAI merupakan tipe pembelajaran kooperatif yang melatih peserta didik berfikir kritis, kreatif, dan efektif. TAI merancang sebuah pembelajaran kelompok dengan cara menyuruh peserta didik bekerja sama dalam kelompok dan bertanggung jawab dalam pengaturan dan pengecekan secara rutin, saling bantu membantu dalam memecahkan masalah dan saling mendorong untuk berprestasi. Selain itu, juga dikarenakan adanya metode hypnoteaching, metode hypnoteaching merupakan metode pembelajaran yang menggunakan teknik komunikasi yang sangat persuasif dan sugestif untuk menyampaikan mata pelajaran. Tujuannya agar peserta didik

${ }^{12}$ Nur Asma, Model Pembelajarn Kooperatif, (Jakarta: 2006), h.557. 
mudah dalam memahami materi pelajaran. ${ }^{13}$ Kelebihan dari pembelajaran hypnoteaching yaitu proses belajar mengajar yang lebih dinamis dan ada interaksi yang baik antara pendidik dan peserta didik. Peserta didik dapat berkembang sesuai dengan bakat dan minatnya, proses pemberian keterampilan banyak diberikan, proses pembelajarannya lebih beragam membuat peserta didik dapat dengan mudah menguasai materi, karena termotivasi lebih untuk belajar.

Sesuai dengan penelitian Rika Lestari, dkk (2014), menjelaskan bahwa penerapan model pembelajaran Team Assisted Individualization (TAI) dapat meningkatkan hasil belajar peserta didik. Nilai rata-rata hasil belajar IPA-fisika peserta didik kelas eksperimen lebih baik daripada kelas kontrol dengan menggunakan uji Independent Sample T-test menggunakan uji pihak kanan. Berdasarkan hasil analisis IndependentSample T-test, nilai F hitung levene test sebesar 2.516 dengan signifikansi $0.117 \geq 0.05 .14$ Selain model pembelajaran, metode juga sangat berpengaruh dalam proses untuk meningkatkan hasil belajar peserta didik dan untuk mencapai nilai ketuntasan, salah satunya metode hypnoteaching. Hal ini sesuai dengan penelitian yang dilakukan Hadi Kasmaja (2016), menjelaskan bahwa dengan menggunakan metode hypnoteaching hasil belajar peserta didik kelas VII SMP Negeri 41

${ }^{13}$ Obee Delapan Setengah, Hypnosis Go: Hidup Lebih Baik, (Jakarta: Bintang Wahyu, 2016), h.106.

${ }^{14}$ Rika Lestari, dkk. "Penerapan Model Pembelajaran Kooperatif Tipe Team Assisted Individualization (TAI) disertai Metode Demonstrasi Dalam Pembelajaran IPA-Fisika di SMP". Jurnal Pendidikan Fisika, Vol. 3 No.3, Desember 2014, h. 275 - 276 
Bulukumba memenuhi kriteria ketuntasan minimal (KKM) sehingga dengan hasil belajar peserta didik kelas VII SMP Negeri 41Bulukumba sebelum diterapkan metode hypnoteaching mencapai skor rata-rata 40,24 dan berada pada kategori tidak tuntas. Sedangkan setelah diajar dengan pembelajaran metode hypnoteaching mencapai skor rata-rata 76,59 dan memenuhi kriteria ketuntasan minimal (KKM) sehingga mencapai ketuntasan klasikal dengan kategori sedang. ${ }^{15}$

Dari hasil analisis data diatas dapat disimpulkan bahwa model pembelajaran Team Assisted Individualization (TAI) dengan menggunakan metode Hypnoteaching dapat meningkatkan hasil belajar peserta didik pada pembelajaran fisika. Dengan meningkatnya hasil belajar yang dialami oleh peserta didik, maka akan bertambah pemahaman peserta didik terhadap setiap materi yang diajarkan dan pencapaian KKM pun akan dapat tercapai. Berdasarkan hasil analisis data menggunakan uji-t pun juga menunjukkan adanya peningkatan hasil belajar, dimana $t_{\text {hitung }}>$ $t_{\text {tabel }}$ yaitu 1,80 $>1,68$ maka $\mathrm{H}_{\mathrm{o}}$ ditolak dan $\mathrm{H}_{\mathrm{a}}$ diterima. Sehingga hipotesis menyatakan bahwa terdapat perbedaan yang signifikan yaitu hasil belajar peserta didik yang dibelajarkan dengan model pembelajaran Team Assisted Individualization (TAI) dengan menggunakan metode Hypnoteaching lebih tinggi dari hasil belajar peserta didik secara konvensional.

\section{Respon Peserta Didik}

${ }^{15}$ Hadi Kasmaja. "Efektivitas Implementasi Metode Hypnoteaching untuk Meningkatkan Motivasi dan Hasil Belajar Matematika pada Siswa SMP Negeri". Journal Of EST, Vol. 2 No.1, April 2016, h. 33 - 34 
Berdasarkan hasil analisis respon peserta didik terhadap pembelajaran penggunaan model pembelajaran Team Assisted Individualization (TAI) dengan menggunakan metode Hypnoteaching diperoleh sebagian besar dari peserta didik setuju terhadap pembelajaran yang menggunakan model pembelajaran Team Assisted Individualization (TAI) dengan menggunakan metode Hypnoteaching. Kita ketahui bahwa setiap peseta didik memiliki kemampuan dan keinginan belajar yang berbeda-beda, untuk itu keberhasilan peserta didik sangat ditentukan oleh respon peserta didik terhadap suatu model dan metode pembelajaran yang diterapkan oleh seorang guru. Berdasarkan angket respon yang dibagikan kepada peserta didik terhadap model pembelajaran Team Assisted Individualization (TAI) dengan menggunakan metode Hypnoteaching pada materi gejala pemanasan global dapat diketahui keseluruhan persentase rata-rata pilihan peserta didik dengan kriteria sangat setuju (SS) $=32,66 \%$, setuju $(\mathrm{S})=64,66 \%$, tidak setuju (TS) $=2,66 \%$ dan sangat tidak setuju (STS) $=0 \%$.

Berdasarkan analisis respon peserta didik di atas, dapat dikatakan positif terhadap pengaruh model pembelajaran Team Assisted Individualization (TAI) dengan menggunakan metode Hypnoteaching, karena jawaban peserta didik pada setiap pernyataan rata-rata memilih jawaban "setuju" dengan persentase 64,66\%. Sehingga, model pembelajaran Team Assisted Individualization (TAI) dengan menggunakan metode Hypnoteaching dapat membantu peserta didik untuk memahami materi gejala pemanasan global, dapat bekerja sama sesama teman, aktif dan bersemangat untuk memulai proses belajar mengajar secara efektif. 


\section{Kesimpulan}

Berdasarkan hasil penelitian yang telah dilakukan melalui pengaruh model Team Assisted Individualization (TAI) dengan menggunakan metode Hypnoteaching terhadap hasil belajar peserta didik pada materi gejala pemanasan global di SMAN 9 Banda Aceh, maka dapat disimpulkan sebagai berikut:

1. Model pembelajaran Team Assisted Individualization (TAI) dengan menggunakan metode Hypnoteaching berpengaruh secara signifikan terhadap hasil belajar fisika pada materi gejala pemanasan global, hal ini dapat ditunjukkan dari nilai rerata pretest dalam pembelajaran Team Assisted Individualization (TAI) dengan menggunakan metode Hypnoteaching adalah 47,18 dan setelah dilakukan pembelajaran dengan Model pembelajaran Team Assisted Individualization (TAI) dengan menggunakan metode Hypnoteaching nilai rerata post test menjadi 76,98. Hal ini diperkuat dengan hasil pengujian hipotesis dengan uji-t. Hasil uji-t post test pada taraf $a=0,05$ didapat $t_{\text {hitung }} 4,23$ dengan $t_{\text {tabel }} 1,68$. Hal ini menunjukkan bahwa terdapat pengaruh model pembelajaran Team Assisted Individualization (TAI) dengan menggunakan metode Hypnoteaching terhadap hasil belajar peserta didik pada materi gejala pemanasan global kelas XI di SMAN 9 Banda Aceh.

2. Pengaruh model pembelajaran Team Assisted Individualization (TAI) dengan menggunakan metode Hypnoteaching terhadap hasil belajar peserta didik pada materi gejala pemanasan global memperoleh respon setuju dari peserta didik, hal ini dibuktikan dari hasil respon peserta didik yang menjawab setuju (S) adalah 
$64,66 \%$ dan respon peserta didik yang menjawab sangat setuju (SS) adalah 32,66 \%, sedangkan respon peserta didik yang menjawab tidaak setuju (TS) adalah 2,66 \% dan respon peserta didik yang menjawab sangat tidak setuju (STS) adalah $0 \%$. Sehingga dapat disimpulkan bahwa model pembelajaran Team Assisted Individualization (TAI) dengan menggunakan metode Hypnoteaching membuat peserta didik aktif dan semangat dalam belajar sehingga dapat meningkatkan hasil belajar peserta didik.

\section{J. Saran}

Berdasarkan hasil yang diperoleh dari penelitian ini, maka penulis mengemukakan beberapa saran, yaitu:.

1. Bagi pendidik bidang studi fisika diharapkan dapat menerapkan model pembelajaran Team Assisted Individualization (TAI) dengan menggunakan metode Hypnoteaching pada proses pembelajaran fisika.

2. Bagi pendidik bidang studi fisika sebaiknya dapat memilih dan menentukan model dan metode pembelajaran yang bervariasi sesuai dengan materi yang akan diajarkan, agar dapat terciptanya suasana aktif dalam proses pembelajaran sehingga tujuan pembelajaran yang telah direncanakan dapat tercapai.

3. Diharapkan kepada peneliti selanjutnya untuk dapat memperhatikan manajemen waktu dalam prosess pembelajaran. 


\section{Daftar Pustaka}

Arikunto, Suharsimi. (2006). Prosedur Penelitian Suatu Pendekatan Praktek. Jakarta: Rineka Cipta.

Asma, Nur. (2006). Model pembelajaran Kooperatif. Jakarta: Dediknas.

Idris, S. (2015). The Internalization of Democratic Values into Education and Their Relevance to Islamic Education Development (Synthetic, Analytic, and Eclectic Implementation of John Dewey's Thoughts). Advanced Science Letters, 21 (7), 2301- 2304. https://doi.org/10.1166/asl.2015.6257

Idris, S. (2017). Learning by Conscience as a New Paradigm in Education. Advanced Science Letters, 23(2), 853-856. https://doi.org/10.1166/asl.2017.7447

Idris, S., \& Ramly, F. (2016). Dimensi Filsafat Ilmu dalam Diskursus Integrasi Ilmu. Yogyakarta: Darussalam Publishing

Idris, S., \& Tabrani ZA. (2017). Realitas Konsep Pendidikan Humanisme dalam Konteks Pendidikan Islam. Jurnal Edukasi: Jurnal Bimbingan Konseling, 3(1), 96-113. https:/ / doi.org/10.22373/je.v3i1.1420

Kasmaja, Hadi. “Efektivitas Implementasi Metode Hypnoteaching untuk Meningkatkan Motivasi dan Hasil Belajar Matematika pada Siswa SMP Negeri". Journal Of EST, Vol. 2 No.1, April 2016.

Koesoema A, Doni. (2007). Pendidikan Karakter. Jakarta: Grasindo.

Lestari, Rika, dkk. "Penerapan Model Pembelajaran Kooperatif Tipe Team Assisted Individualization (TAI) disertai Metode Demonstrasi Dalam Pembelajaran IPA-Fisika di SMP”. Jurnal Pendidikan Fisika, Vol. 3 No.3, Desember 2014.

Obee Delapan Setengah. (2016). Hypnosis Go: Hidup Lebih Baik, Jakarta: Bintang Wahyu.

Ridhwan. (2012). Belajar Mudah Penelitian untuk Guru-Karyawan dan Peneliti Pemula. Bandung: Alfabeta.

Sudjana, Nana. (1989). Dasar-dasar dan Proses Belajar Mengajar, Bandung: Sinar Baru.

Sugiyono. (2014). Metode Penelitian Kuantitatif, Kualitatif, dan RED. Bandung: CV. Alfabeta. 
Tabrani ZA \& Murziqin, R. (2015). Political Education in Maturation Democracy in Indonesia. British Journal of Political Science, 45 (1), 215-226

Tabrani ZA, \& Masbur. (2016). Islamic Perspectives on the Existence of Soul and Its Influence in Human Learning (A Philosophical Analysis of the Classical and Modern Learning Theories). JURNAL EDUKASI: Jurnal Bimbingan Konseling, 1(2), 99-112. Retrieved from http://jurnal.arraniry.ac.id/index.php/cobaBK/article/view/600

Tabrani ZA, \& Walidin, W. (2017). Hak-Hak Non Muslim dalam Pemerintahan: Konsep Dien wa Ni'mah dan Pluralisme Agama di Indonesia. Ijtima i: International Journal of Government and Social Science, 3(1), 15-30.

Tabrani ZA. (2009). Ilmu Pendidikan Islam (antara Tradisional dan Modern). Kuala Lumpur: Al-Jenderami Press.

Tabrani ZA. (2011a). Dynamics of Political System of Education Indonesia. International Journal of Democracy, 17(2), 99-113.

Tabrani ZA. (2011b). Nalar Agama dan Negara dalam Perspektif Pendidikan Islam. (Suatu Telaah Sosio-Politik Pendidikan Indonesia). Millah Jurnal Studi Agama, 10(2), 395-410.

Tabrani ZA. (2012). Future Life of Islamic Education in Indonesia. International Journal of Democracy, 18(2), 271-284.

Tabrani ZA. (2013a). Modernisasi Pengembangan Pendidikan Islam (Suatu Telaah Epistemologi Pendidikan). Serambi Tarbawi, 1(1), 6584 .

Tabrani ZA. (2013b). Pengantar Metodologi Studi Islam. Banda Aceh: SCAD Independent.

Tabrani ZA. (2013c). Urgensi Pendidikan Islam dalam Pemberdayaan Masyarakat. Jurnal Sintesa, 13(1), 91-106.

Tabrani ZA. (2013d). Kebijakan Pemerintah dalam Pengelolaan Satuan Pendidikan Keagamaan Islam (Tantangan Terhadap Implementasi Manajemen Berbasis Sekolah). Serambi Tarbawi, 1(2), 65-84.

Tabrani ZA. (2014a). Dasar-Dasar Metodologi Penelitian Kualitatif. Yogyakarta: Darussalam Publishing. 
Tabrani ZA. (2014b). Islamic Studies dalam Pendekatan Multidisipliner (Suatu Kajian Gradual Menuju Paradigma Global). Jurnal Ilmiah Peuradeun, 2(2), 211-234.

Tabrani ZA. (2014c). Isu-Isu Kritis dalam Pendidikan Islam Perspektif Pedagogik Kritis. Jurnal Ilmiah Islam Futura, 13(2), 250-270. https://doi.org/10.22373/jiif.v13i2.75

Tabrani ZA. (2014d). Penelitian Tindakan Kelas (Buku Ajar)-Bahan Ajar untuk Mahasiswa Program Strata Satu (S-1) dan Program Profesi Keguruan $(P P G)$. Banda Aceh: FTK Ar-Raniry Press.

Tabrani ZA. (2015a). Arah Baru Metodologi Studi Islam. Yogyakarta: Penerbit Ombak.

Tabrani ZA. (2015b). Persuit Epistemology of Islamic Studies (Buku 2 Arah Baru Metodologi Studi Islam). Yogyakarta: Penerbit Ombak.

Tabrani ZA. (2015c). Keterkaitan Antara Ilmu Pengetahuan dan Filsafat (Studi Analisis atas QS. Al-An`am Ayat 125). Jurnal Sintesa, 14(2), $1-14$.

Tabrani ZA. (2016). Perubahan Ideologi Keislaman Turki (Analisis GeoKultur Islam dan Politik Pada Kerajaan Turki Usmani). JURNAL EDUKASI: Jurnal Bimbingan Konseling, 2(2), 130-146. https://doi.org/10.22373/je.v2i2.812

Tabrani ZA. (2017). Menggugat Logika Nalar Rasionalisme Aristoteles. Yogyakarta: Mizan.

Walidin, W., Idris, S., \& Tabrani ZA. (2015). Metodologi Penelitian Kualitatif $\mathcal{E}$ Grounded Theory. Banda Aceh: FTK Ar-Raniry Press. 
